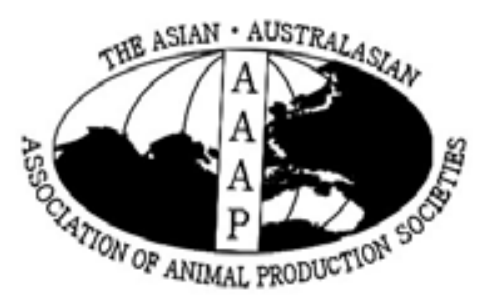

Asian-Aust. J. Anim. Sci.

Vol. 20, No. 2 : 220 - 228

February 2007

unw.ajasinfo

\title{
Effect of Tannins in Acacia nilotica, Albizia procera and Sesbania acculeata Foliage Determined In vitro, In sacco, and In vivo
}

\author{
M. R. Alam*, M. R. Amin, A. K. M. A. Kabir, M. Moniruzzaman and D. M. McNeill ${ }^{1}$ \\ Department of Animal Science, Bangladesh Agricultural University, Mymensingh-2202, Bangladesh
}

\begin{abstract}
The nutritive value and the effect of tannins on the utilization of foliage from three commonly used legumes, Acacia nilotica, Albizia procera, and Sesbania acculeata, were determined. Three mature rumen-fistulated bullocks were used to study in sacco degradability and twelve adult sheep were randomly allocated on the basis of live weight to 4 groups of 3 in each to study the in vivo digestibility of the foliages. In all foliages, the contents of crude protein (17 to $24 \%$ of DM) were high. Fibre was especially high in Albizia (NDF $58.8 \%$ of DM vs. $21 \%$ in Sesbania and $15.4 \%$ in Acacia). Contents of both hydrolysable (4.4 to $0.05 \%$ ) and condensed tannins (1.2 to $0.04 \%$ ) varied from medium to low in the foliages. Acacia contained the highest level of total phenolics (20.1\%), protein precipitable phenolics (13.2\%) and had the highest capacity to precipitate protein (14.7\%). Drying in shade reduced the tannin content in Acacia and Albizia by 48.6 and $69.3 \%$ respectively. The foliages ranked similarly for each of the different methods used to estimate tannin content and activity. Acacia and Sesbania foliage was highly degradable (85-87\% potential degradability of DM in sacco), compared to Albizia (52\%), indicating a minimal effect of tannins in Acacia and Sesbania. Yet, in vitro, the tannins in the Acacia inhibited microbial activity more than those in Albizia and Sesbania. Following the addition of polyethylene glycol to neutralise the tannins, gas production and microbial growth increased by 59\% and $0.09 \mathrm{mg}$ RNA equiv./dg microbial yield respectively in the Acacia, compared to $16-17 \%$ and $0.06 \mathrm{mg}$ RNA equiv./dg microbial yield in the other foliages. There was a trend for low in vivo apparent digestibility of $\mathrm{N}$ in the Acacia (43.2\%) and Albizia (44.2\%) compared to the Sesbania (54.5\%) supplemented groups. This was likely to be due to presence of tannins. Consistent with this was the low $\mathrm{N}$ retention $(0.22$ and $0.19 \mathrm{~g} \mathrm{~N} / \mathrm{g} \mathrm{NI})$ in sheep supplemented with Acacia and Albizia compared to that for the Sesbania (0.32). Similarly, a trend for poor microbial $\mathrm{N}$ yield was observed in sheep fed these foliages. Across the foliages tested, an increase in tannin content was associated with a reduction in ruminal fermentation, $\mathrm{N}$ digestibility and $\mathrm{N}$ retention. For overall nutritive value, Sesbania proved to be the superior forage of the three tested. (Key Words : Acacia, Albizia, Sesbania, Polyphenolics, Digestibility, Purine Derivative)
\end{abstract}

\section{INTRODUCTION}

In Bangladesh, livestock are mainly reared at a subsistence level to supplement farm income. A scarcity of livestock feed is the major limitation to the success of such systems. Commonly, various tree leaves, flowers, pods and twigs are offered to livestock to augment the feed available in conventional grazing and straw feeding systems. It is estimated that the land allocated to crops, which comprise $60 \%$ of the total land area, provides about $87 \%$ of the feed offered to livestock and is mainly available as byproducts such as straw and crop residues. The remaining $13 \%$ comes from leaves of multipurpose trees, shrubs and herbs (Alam,

\footnotetext{
* Corresponding Author: M. R. Alam. Tel: +88-091-53971, Fax: +88-091-55810, E-mail: mralam@royalten.net.bd

${ }^{1}$ Faculty of Veterinary Science, University of Sydney, Camden NSW, 2570, Australia.

Received February 16, 2006; Accepted May 2, 2006
}

1998).

To supplement crop byproducts, foliage from leguminous trees is being increasingly recognized as a high quality feed resource (Evitayani et al, 2004). However, it remains underutilized. This is in part due to the presence of anti-nutritive factors, such as tannins, often found at excessive levels in the foliage of such trees. The presence of tannins at high levels can significantly restrict intake and the utilization of nutrients, particularly nitrogen (Mangan, 1988; Lawry, 1990; Reed et al., 1990; Pritchard et al., 1992; Kumar, 1992; McNeill et al., 1998; Barry et al., 2001). On the other hand, low levels of tannins in foliage can increase the utilization of crude protein by protecting it from digestion in the rumen thereby increasing the flow of essential amino acids to the small intestine for absorption (Waghorn, 1990; Barry et al., 2001). The increasing importance of various legume tree and shrub foliages in ruminant feeding systems in Bangladesh necessitates the 
need for further studies to define the nutritive values of the common foliages on offer and to understand the limitations imposed by their tannin contents. The present experiment was conducted to investigate the nutritive values and the effect of tannins on dry matter and $\mathrm{N}$ utilization and microbial $\mathrm{N}$ yield in foliage from Acacia nilotica (Acacia), Albizia procera (Albizia) and Sesbania acculeata (Sesbania).

\section{MATERIALS AND METHODS}

\section{Collection and preparation of foliages}

Leaves and pods were harvested from Acacia and Albizia that were approximately 6 years of age and 6 to 7 meters high, and with approximately 2 months of regrowth. Sesbania was harvested 3 months after sowing. Branches were lopped at 1 meter in length from the growing points and the leaves and pods were manually separated. The bulk of the foliages were dried in shade for the feeding trial and another batch of fresh foliage from each tree species was collected and immediately frozen until freeze-drying. This was to minimize the loss of tannins normally caused by drying. Both samples were ground through a $0.5 \mathrm{~mm}$ sieve, bottled and covered with aluminum foil and kept in desiccators for determination of chemical composition. Shade dried samples were also ground through a $1 \mathrm{~mm}$ sieve for fiber analyses, in vitro digestibility and in sacco degradability studies.

\section{Analytical methods}

The proximate composition of shade and freeze-dried samples, for DM (Official method 934.01), OM (Official method 942.05), and $\mathrm{N}$ (Official method 984.13), was determined according to the AOAC (1990). Ash free neutral detergent fiber (NDF), acid detergent fiber (ADF) and lignin were estimated using sodium sulphite according to the method of Faichney and White (1983). Total phenols (TP) were estimated by the Folin-Ciocaltau reagent method and Total tannin (TT) was determined by subtracting the values of polyvinylpolypyrrolidone bound tannins from TP and expressed as tannic acid equivalents (Makkar et al., 1993). Condensed tannin (CT) was determined by oxidation of CT in butanol-HCl reagent in the presence of iron and expressed as leucocyanidin equivalents (Porter et al., 1986). Gallotannin content was determined by hydrolysis to gallic acid with rhodanine and expressed as gallic acid equivalents (Inoue and Hagerman, 1988). Protein precipitatable phenolics were estimated by formation of protein complexes with BSA using the Ferric chloride assay (Makkar et al., 1988). Protein-binding capacity was measured according to the formation of protein-tannin complexes on filter paper by the filter paper-protein
Ponceau S dye assay (Dawra et al., 1988). Tannin content was also assayed by formation of protein tannin complex formed on agarose gel with bovine serum albumen (BSA). The diameter of ring formed was used to indicate the protein precipitation/binding capacity of tannins (Hagerman, 1987). ${ }^{125}$ I was used to label BSA for the Radio-labeled BSA precipitation method and the BSA precipitated was determined from counts and plotted/unit forage DM (Hagerman et al., 1998).

\section{In sacco degradability}

Three matured fistulated bulls were fed ad libitum rice straw, $1.5 \mathrm{~kg}$ each of grass and tree legume foliages and 1 $\mathrm{kg}$ wheat bran per day during the trial. Approximately $3 \mathrm{~g}$ of each shade dried forage sample in decron bags was incubated in triplicate in the rumen for up to $96 \mathrm{hrs}$ and the samples were withdrawn at 4, 8, 16, 24, 36, 48, 72 and $96 \mathrm{~h}$. Immediately after withdrawal the bags were kept in cool water, and to remove adhered feed particles they were washed in cool water in a domestic washing machine for 20 minutes and dried in an oven for about $30 \mathrm{~h}$ at $65^{\circ} \mathrm{C}$ to constant weight. The degradability of DM was calculated using "NAWAY" program developed at the Rowett Research Institute according to Bhargava and Orskov (1987).

\section{In vitro digestibility}

Rumen fluid from 2 adult bulls was used. The bulls were fed on rice straw ad libitum, and $2 \mathrm{~kg}$ each of a concentrate mixture, grass hay and tree foliages per day. Rumen buffer solution was prepared by the addition of bicarbonate buffer solution, macro and micro mineral solutions to rumen fluid according to the recipe given by (Manke et al., 1979). Approximately $375 \mathrm{mg}$ of ground shade dried foliage, with or without $750 \mathrm{mg}$ of PEG added, were put into $100 \mathrm{ml}$ glass syringes, in triplicate, and incubated in the rumen fermentation buffer solution for $24 \mathrm{~h}$ at $39^{\circ} \mathrm{C}$. Gas volume was recorded at $0,3,9,12$ and $24 \mathrm{~h}$ and the effect of tannins on fermentation was determined by the difference between the net gas produced from the syringes with or without PEG, after a correction for gas produced from the incubation of a standard hay (Makkar et al., 1995). After $24 \mathrm{~h}$ of fermentation the contents of syringes were collected in tubes, centrifuge for $30 \mathrm{~min}$ $\left(20,000 \mathrm{~g}\right.$ at $\left.4^{\circ} \mathrm{C}\right)$, washed and centrifuged again. The pellets were freeze-dried and ground in pestle and mortar and microbial mass was estimated from the concentration of ribonucleic acid in the pellets, according to Makkar and Becker (1999).

\section{In vivo digestibility}

A short term in vivo feeding trial was conducted to 
Table 1. Composition of the foliages and the other dietary ingredients (\% DM)

\begin{tabular}{lrrrrc}
\hline & Acacia & Albizia & Sesbania & Hay & Conc. \\
\hline Shade dried & & & & & \\
OM & 79.8 & 78.3 & 76.9 & 77.2 & 81.6 \\
N & 2.9 & 3.1 & 3.7 & 1.4 & 4.9 \\
NDF & 15.4 & 58.8 & 21.0 & 60.9 & - \\
ADF & 12.8 & 43.2 & 14.8 & 36.4 & - \\
Lignin & 4.5 & 20.9 & 4.3 & 23.9 & - \\
Freeze dried & & & & & \\
OM & 86.3 & 86.8 & 83.4 & & \\
N & 4.1 & 3.9 & 5.8 & & \\
NDF & 14.7 & 60.3 & 18.5 & & \\
ADF & 13.1 & 41.7 & 12.1 & & \\
Lignin & 4.1 & 18.5 & 5.9 & & \\
\hline OM = Organic matter; N = Nitrogen. \\
NDF = Neutral detergent fibre; ADF = Acid detergent fibre.
\end{tabular}

determine the effect of each shade dried tanniniferous foliage species on digestibility, $\mathrm{N}$ balance, and microbial protein yield by purine derivatives method (Chen et al., 1990). Twelve adult sheep with a mean live weight of 12.5 $( \pm 2.15) \mathrm{kg}$ were used in the experiment. The animals were randomly allocated on the basis of live weight to 4 groups with 3 sheep in each and were housed in individual metabolic crates. Water was available at all times. The sheep were offered the shade dried foliages over 3 feeding periods, with a set level of foliage offered at each period. The amounts of foliage offered were calculated to provide 15,10 and $5 \mathrm{~g}$ of $\mathrm{N} / \mathrm{d}$ for the first, second and third feeding periods respectively. In addition to a basal amount of grass hay (95 g DM/d), at each feeding the levels of foliage fed were: Acacia 495, 330 and 165 g/d; Albizia, 330, 220 and
$110 \mathrm{~g} / \mathrm{d}$; Sesbania 410, 270 and $135 \mathrm{~g} / \mathrm{d}$. Across the successive feeding periods the control group was offered a concentrate mixture of wheat bran, oil cake and salt fed at 430, 220 and $140 \mathrm{~g} / \mathrm{d}$ respectively, in addition to the basal $95 \mathrm{~g} / \mathrm{d}$ of grass hay. Each trial comprised $7 \mathrm{~d}$ preliminary, 7 $\mathrm{d}$ collection and $10 \mathrm{~d}$ rest periods. The sheep were rerandomized to treatments after each trial.

During each feeding trial, feed intake, faces and urine voided were measured daily. Faces were bulked in a freezer, sub-sampled after the collection period, freeze-dried and ground for chemical analysis. Urine was collected in $10 \%$ sulphuric acid daily, measured, processed and kept frozen for each sheep prior to the determination of purine derivatives and microbial $\mathrm{N}$ yield according to IAEATECDOC-945 (1997).

\section{Statistical analysis}

The data of in vitro and in vivo parameters were analyzed in $3 \times 2$ and $4 \times 3$ factorial arrangements using randomized block design. In sacco degradability was determined by regression analysis using the General Linear Model Procedures. Pearson's correlation coefficient was used to estimate associations between tannin contents determined by each of the assays used. General Linear Models Procedure of SAS version 6.03 (1988) was used to analyze the data and means were separated by Duncan's multiple range test.

\section{RESULTS}

\section{Chemical composition}

The chemical composition of foliages, grass hay and

Table 2. Contents of tannins in the foliages as defined by a variety of tannin assays before and after shade drying

\begin{tabular}{|c|c|c|c|c|c|c|}
\hline & \multicolumn{2}{|c|}{ Acacia } & \multicolumn{2}{|c|}{ Albizia } & \multicolumn{2}{|c|}{ Sesbania } \\
\hline & FD & SD & FD & SD & FD & SD \\
\hline $\begin{array}{l}\text { Total phenols } \\
(\mathrm{mg} / \mathrm{dg} \mathrm{DM})^{\mathrm{a}}\end{array}$ & $20.08 \pm 0.08$ & $11.94 \pm 0.08$ & $13.90 \pm 0.07$ & $5.92 \pm 0.05$ & $4.93 \pm 0.08$ & $4.99 \pm 0.03$ \\
\hline $\begin{array}{l}\text { Tannin } \\
\quad(\mathrm{mg} \mathrm{TA} / \mathrm{dg} \mathrm{DM})^{\mathrm{a}}\end{array}$ & $13.61 \pm 0.03$ & $9.16 \pm 0.04$ & $6.62 \pm 0.02$ & $3.91 \pm 0.02$ & $2.60 \pm 0.02$ & $2.65 \pm 0.04$ \\
\hline $\begin{array}{l}\text { Condensed tannin } \\
\text { (mg TA/dg DM) }\end{array}$ & $1.18 \pm 0.00$ & $0.81 \pm 0.00$ & $0.84 \pm 0.00$ & $0.51 \pm 0.00$ & $0.43 \pm 0.00$ & $0.27 \pm 0.00$ \\
\hline $\begin{array}{l}\text { Gallotannins } \\
\qquad(\mathrm{mg} \mathrm{GA} / \mathrm{dg} \mathrm{DM})^{\mathrm{c}}\end{array}$ & $4.43 \pm 0.01$ & $3.73 \pm 0.02$ & $1.92 \pm 0.00$ & $1.25 \pm 0.00$ & $0.05 \pm 0.00$ & $0.04 \pm 0.00$ \\
\hline $\begin{array}{l}\text { Protein precipitable phenolics } \\
\text { (mg TA/dg DM) }\end{array}$ & $14.7 \pm 0.06$ & $13.2 \pm 0.05$ & $19.5 \pm 0.03$ & $6.8 \pm 0.03$ & $5.3 \pm 0.02$ & $3.8 \pm 0.04$ \\
\hline \multicolumn{7}{|l|}{ Filter paper assay } \\
\hline (mg BSA pptd/dg DM) & $17.8 \pm 0.07$ & $18.9 \pm 0.05$ & $19.2 \pm 0.08$ & $11.2 \pm 0.07$ & $1.9 \pm 0.00$ & $1.9 \pm 0.00$ \\
\hline$(\mathrm{mg} \mathrm{TA} / \mathrm{dg} \mathrm{DM})^{\mathrm{a}}$ & $13.9 \pm 0.05$ & $15.1 \pm 0.05$ & $15.1 \pm 0.06$ & $11.2 \pm 0.03$ & $1.1 \pm 0.00$ & $1.1 \pm 0.00$ \\
\hline $\begin{array}{l}\text { Radial diffusion assay } \\
\quad(\mathrm{mg} \mathrm{TA} / \mathrm{dg} \mathrm{DM})^{\mathrm{a}}\end{array}$ & $14.8 \pm 0.03$ & $13.4 \pm 0.04$ & $3.6 \pm 0.01$ & $2.5 \pm 0.00$ & $0.9 \pm 0.00$ & $0.5 \pm 0.00$ \\
\hline $\begin{array}{l}\text { Radio-labeled protein } \\
\text { precipitable phenolics } \\
\text { (mg BSA pptd/dg DM) }\end{array}$ & $14.2 \pm 0.02$ & $13.9 \pm 0.03$ & $15.7 \pm 0.06$ & $13.2 \pm 0.03$ & $1.9 \pm 0.00$ & $2.0 \pm 0.00$ \\
\hline
\end{tabular}


Table 3. Mean in sacco degradability (\%) parameters of the shade dried foliages

\begin{tabular}{lccccc}
\hline Foliages & $\mathrm{a}$ & $\mathrm{b}$ & $\mathrm{a}+\mathrm{b}$ & $\mathrm{c}$ & $\mathrm{RSD}$ \\
\hline Acacia & 25.13 & 59.55 & 84.68 & 0.052 & 1.893 \\
Albizia & 20.10 & 31.54 & 51.64 & 0.033 & 1.828 \\
Sesbania & 23.58 & 62.97 & 86.55 & 0.038 & 1.631 \\
\hline
\end{tabular}

$\mathrm{a}=$ Solubility of dry matter; $\mathrm{b}=$ Extent of digestion in the rumen. $\mathrm{a}+\mathrm{b}=$ Potential digestibility; $\mathrm{c}=$ Rate of digestion.

concentrate mixture is shown in Table 1. Each of foliages, shade dried, were rich in $\mathrm{N}$ and contained on average 2.3 times more $\mathrm{N}$ than the grass hay. The concentrations of NDF, ADF, and lignin in the Albizia and the grass hay were similar and high compared to those found in the Acacia and Sesbania foliage. The shade dried Albizia foliage contained approximately 1.7, 2.6, and 5.4 times more NDF, ADF, and lignin than the average of each for the Sesbania and Acacia foliage.

\section{Tannin contents}

All of the tannin assays showed high values for Acacia and Albizia and low for Sesbania (Table 2). Drying of all the foliages in shade reduced the concentration of tannins, according to almost all of the assays, by an average of 55\%, as indicated from the differences of the values between freeze and shade dried samples. The reduction was most notable for the TP, TT, and CT assays for the Acacia and Albizia.

\section{In sacco degradability of foliages}

The potential digestibility of DM was similarly high in the Acacia and Sesbania foliage (84.68 vs. 86.55\%) compared to the relatively poor degradability of the Albizia foliage, at $51.64 \%$ (Table 3 ). This was largely due to the poor extent of digestion in the rumen for the Albizia, which was approximately half that observed for the Acacia and Sesbania. The highest rate of digestion was observed for the
Acacia foliage and lowest for the Albizia.

\section{Gas production following in vitro digestion}

The addition of PEG to the incubation increased gas production and the production of microbial RNA for all foliages (Table 4). The increases were highest for the Acacia, compared to the responses for the Albizia and Sesbania which were similarly low. Gas production was 3.6 times higher and microbial RNA increases 1.4 times higher for the Acacia compared the average of the Albizia and Sesbania.

\section{Correlation between tannin concentrations and in vitro gas production}

The correlation coefficient between the tannin concentrations or activities as measured by each of the assays used and the increase in gas production following the addition of PEG is shown in Table 5. All assays for tannin content and activity were positively correlated with gas production increase $(\mathrm{p}<0.05)$, with the exception of CT $(\mathrm{R}=$ 0.76).

\section{Intake and in vivo digestibility}

Within each level of $\mathrm{N}$ offered, intakes of DM were statistically similar across treatments (Table 6). However, the apparent digestibility of $\mathrm{DM}, \mathrm{OM}$, and $\mathrm{N}$ were consistently lower for the treatments containing the shade dried foliage compared to the hay+concentrate control diet $(\mathrm{p}<0.05)$. Of the shade dried foliages DM and OM digestibility tended to be lower for Albizia whilst $\mathrm{N}$ digestibility tended to be lowest for the Acacia $(\mathrm{p}<0.05)$.

\section{Utilisation of $\mathbf{N}$}

At the highest level of $\mathrm{N}$ intake, $\mathrm{N}$ balance was depressed in the sheep fed the Acacia and Albizia whereas

Table 4. Gas production and the associated production of microbial RNA following in vitro digestion of the foliages before and after the addition of PEG

\begin{tabular}{|c|c|c|c|c|c|c|c|c|}
\hline & \multicolumn{2}{|c|}{ Total gas production (ml) } & \multirow{2}{*}{$\begin{array}{l}\text { Increase in gas } \\
\text { production (\%) }\end{array}$} & \multirow{2}{*}{$\begin{array}{l}\text { Level of } \\
\text { sig. }\end{array}$} & \multicolumn{2}{|c|}{$\begin{array}{l}\text { Rumen microbes } \\
\text { (mg RNA equi/dg) }\end{array}$} & \multirow{2}{*}{$\begin{array}{l}\text { Increase in microbes } \\
\text { - (mg RNA equi/dg) }\end{array}$} & \multirow{2}{*}{$\begin{array}{l}\text { Level of } \\
\text { sig. }\end{array}$} \\
\hline & -PEG & $+\mathrm{PEG}$ & & & -PEG & $+\mathrm{PEG}$ & & \\
\hline Acacia & 15.44 & 24.58 & 59.21 & $* *$ & 0.30 & 0.39 & 0.09 & $*$ \\
\hline Albizia & 4.95 & 5.80 & 17.17 & $*$ & 0.13 & 0.19 & 0.06 & $*$ \\
\hline Sesbania & 17.72 & 20.58 & 16.14 & $*$ & 0.13 & 0.19 & 0.06 & * \\
\hline
\end{tabular}

DM = Dry matter; PEG = Polyethylene glycol; RNA = Ribonucleic acid; dg = Decigram.

Significant differences ${ }^{* *} \mathrm{p}<0.01 ;{ }^{*} \mathrm{p}<0.05$.

Table 5. Correlation coefficients between the concentrations of tannins determinations by each of the tannin assays including the gas production assay

\begin{tabular}{|c|c|c|c|c|c|}
\hline & Total phenols & Total tannins & Condensed tannins & Gallotannins & Gas production \\
\hline Total phenols & & $0.99 *$ & $0.83^{*}$ & $0.98 *$ & $0.99 *$ \\
\hline Total tannins & & & $0.86^{*}$ & $0.99 *$ & $0.98 *$ \\
\hline Condensed tannins & & & & $0.92 *$ & 0.76 \\
\hline Gallotannins & & & & & $0.95 *$ \\
\hline
\end{tabular}

\footnotetext{
* Significant differences $(\mathrm{p}<0.05)$.
} 
Table 6. Intake and in vivo digestibility (\%) of diets supplemented with the foliages as compared to the concentrate supplemented diet, offered at 3 levels of $\mathrm{N}$ intake

\begin{tabular}{|c|c|c|c|c|c|c|}
\hline $\begin{array}{l}\mathrm{N} \text { intake } \\
\text { level (g/d) }\end{array}$ & Parameters & Hay+concentrate & Hay+Acacia & Hay+Albizia & Hay+Sesbania & SEM \\
\hline \multirow[t]{5}{*}{15} & DMI (g/LW/d) & 28.6 & 25.5 & 29.1 & 35.2 & 0.69 \\
\hline & Digestibility: & & & & & \\
\hline & $\mathrm{DM}$ & $75.8^{\mathrm{a}}$ & $51.3^{\mathrm{b}}$ & $41.5^{\mathrm{c}}$ & $51.1^{\mathrm{b}}$ & 0.04 \\
\hline & $\mathrm{OM}$ & $78.7^{\mathrm{a}}$ & $53.0^{\mathrm{b}}$ & $44.6^{\mathrm{b}}$ & $53.9^{\mathrm{b}}$ & 0.04 \\
\hline & $\mathrm{N}$ & $77.5^{\mathrm{a}}$ & $51.9^{\mathrm{b}}$ & $45.9^{\mathrm{b}}$ & $61.4^{\mathrm{bc}}$ & 0.03 \\
\hline \multirow[t]{5}{*}{10} & DMI (g/LW/d) & 16.0 & 20.8 & 25.7 & 17.6 & 0.24 \\
\hline & Digestibility: & & & & & \\
\hline & $\mathrm{DM}$ & $69.2^{\mathrm{a}}$ & $60.4^{\mathrm{ac}}$ & $45.5^{\mathrm{b}}$ & $53.5^{\mathrm{c}}$ & 0.03 \\
\hline & $\mathrm{OM}$ & $72.4^{\mathrm{a}}$ & $63.4^{\mathrm{ac}}$ & $48.2^{\mathrm{b}}$ & $57.5^{\mathrm{bc}}$ & 0.02 \\
\hline & $\mathrm{N}$ & $64.5^{\mathrm{a}}$ & $39.9^{\mathrm{b}}$ & $45.0^{\mathrm{c}}$ & $49.4^{\mathrm{c}}$ & 0.03 \\
\hline \multirow[t]{5}{*}{5} & DMI (g/LW/d) & 17.2 & 19.1 & 13.6 & 15.1 & 0.23 \\
\hline & Digestibility: & & & & & \\
\hline & $\mathrm{DM}$ & $63.7^{\mathrm{a}}$ & $51.9^{\mathrm{b}}$ & $47.1^{\mathrm{b}}$ & $51.2^{\mathrm{b}}$ & 0.03 \\
\hline & $\mathrm{OM}$ & $68.8^{\mathrm{a}}$ & $51.8^{\mathrm{bc}}$ & $43.5^{\mathrm{b}}$ & $55.8^{\mathrm{bc}}$ & 0.04 \\
\hline & $\mathrm{N}$ & $67.4^{\mathrm{a}}$ & $38.0^{\mathrm{b}}$ & $41.7^{\mathrm{b}}$ & $52.7^{\mathrm{C}}$ & 0.04 \\
\hline
\end{tabular}

$\mathrm{DM}=$ Dry matter; OM = Organic matter; $\mathrm{N}$ = Nitrogen; SEM = Standard error of mean, LW = Live weight.

Different superscripts within rows denote significant differences $(\mathrm{p}<0.05)$.

Table 7. Retention of nitrogen (mg/kg LW/d) by sheep offered diets supplemented with the foliages as compared to the concentrate supplemented diet, at 3 levels of $\mathrm{N}$ intake

\begin{tabular}{|c|c|c|c|c|c|c|}
\hline $\begin{array}{l}\mathrm{N} \text { intake } \\
\text { level (g/d) }\end{array}$ & Parameters & Hay+concentrate & Hay+Acacia & Hay+Albizia & Hay+Sesbania & SEM \\
\hline \multirow[t]{5}{*}{15} & $\mathrm{~N}$ intake & $1,193^{\mathrm{a}}$ & $686^{\mathrm{b}}$ & $853^{b}$ & $1,143^{\mathrm{a}}$ & 75.5 \\
\hline & Faecal N & $272^{\mathrm{a}}$ & $325^{\mathrm{ab}}$ & $459^{\mathrm{b}}$ & $443^{b}$ & 30.8 \\
\hline & Urinery $\mathrm{N}$ & $449^{\mathrm{a}}$ & $106^{\mathrm{b}}$ & $197^{\mathrm{b}}$ & $241^{\mathrm{b}}$ & 45.2 \\
\hline & $\mathrm{N}$ balance & $472^{\mathrm{a}}$ & $254^{\mathrm{b}}$ & $197^{\mathrm{b}}$ & $459^{\mathrm{a}}$ & 43.6 \\
\hline & $\begin{array}{l}\text { Net } N \text { retained } \\
\quad \text { (g N/g NI) }\end{array}$ & 0.40 & 0.37 & 0.23 & 0.40 & \\
\hline \multirow[t]{5}{*}{10} & $\mathrm{~N}$ intake & 622 & 470 & 631 & 541 & 28.9 \\
\hline & Faecal N & 223 & 254 & 349 & 273 & 18.9 \\
\hline & Urinery $\mathrm{N}$ & 209 & 129 & 220 & 166 & 16.1 \\
\hline & $\mathrm{N}$ balance & 190 & 59 & 62 & 102 & 26.1 \\
\hline & $\begin{array}{l}\text { Net } N \text { retained } \\
\quad \text { (g N/g NI) }\end{array}$ & 0.31 & 0.13 & 0.10 & 0.19 & \\
\hline \multirow[t]{5}{*}{5} & $\mathrm{~N}$ intake & 539 & 435 & 320 & 408 & 31.7 \\
\hline & Faecal N & 176 & 277 & 205 & 194 & 20.4 \\
\hline & Urinery $\mathrm{N}$ & $183^{\mathrm{a}}$ & $93^{\mathrm{a}}$ & $43^{b}$ & $62^{\mathrm{a}}$ & 18.6 \\
\hline & $\mathrm{N}$ balance & 180 & 65 & 65 & 152 & 18.7 \\
\hline & $\begin{array}{l}\text { Net } N \text { retained } \\
\quad(g \text { N/g NI) }\end{array}$ & 0.33 & 0.15 & 0.23 & 0.37 & \\
\hline
\end{tabular}

LW = Live weight; $\mathrm{N}$ = Nitrogen; NI = Nitrogen intake; SEM = Standard error of mean.

Different superscripts within rows denote significant differences $(\mathrm{p}<0.01)$.

$\mathrm{N}$ balance in the sheep fed the Sesbania remained as high as that for the sheep fed the control diet containing the concentrate $(\mathrm{p}<0.05)$. At the other levels of $\mathrm{N}$ a similar pattern emerged but did not reach statistical significance.

\section{Yield of purine derivatives and microbial $\mathbf{N}$ by sheep}

Only at the highest level of $\mathrm{N}$ offered were significant treatment effects observed, with microbial $\mathrm{N}$ flows highest for the sheep fed the control diet containing concentrate and the sheep fed Acacia compared to Albizia and Sesbania $(p<0.05$, Table 8$)$. The comparatively high production of microbial $\mathrm{N}$ in the sheep fed Acacia was despite them tending to have a lower intake of DM and $\mathrm{N}$ than the other treatments ( $p>0.05$, Tables 6 and 7$)$.

\section{DISCUSSION}

The tanniniferous foliages compared in this study were grown under similar climatic and edaphic conditions and were harvested at approximately the same stage of regrowth. Therefore, the nutritional differences observed between them may be considered genetic rather than environmental. 
Table 8. Excretion of purine derivative (PDe) and estimated microbial $\mathrm{N}$ yield by sheep offered diets supplemented with the foliages as compared to the concentrate supplemented diet, at 3 levels of $\mathrm{N}$ intake

\begin{tabular}{|c|c|c|c|c|c|c|}
\hline $\begin{array}{l}\mathrm{N} \text { intake } \\
\text { level (g/d) }\end{array}$ & Parameters & Hay+concentrate & Hay+Acacia & Hay+Albizia & Hay+Sesbania & SEM \\
\hline \multirow[t]{5}{*}{15} & Total PDe (mmol/d) & $8.50^{\mathrm{a}}$ & $8.12^{\mathrm{a}}$ & $6.44^{\mathrm{b}}$ & $6.78^{\mathrm{b}}$ & 0.38 \\
\hline & Allatoin (mmol/d) & 6.25 & 5.39 & 4.78 & 4.95 & 0.32 \\
\hline & $\begin{array}{c}\text { Xan+Hypoxan } \\
(\mathrm{mmol} / \mathrm{d})\end{array}$ & 1.05 & 1.22 & 0.43 & 0.69 & 0.13 \\
\hline & Uric acid (mmol/d) & 1.21 & 1.51 & 1.23 & 1.14 & 0.12 \\
\hline & Microbial N (g/d) & $6.84^{\mathrm{a}}$ & $6.07^{\mathrm{a}}$ & $4.72^{\mathrm{b}}$ & $5.11^{\mathrm{b}}$ & 0.32 \\
\hline \multirow[t]{5}{*}{10} & Total PDe (mmol/d) & 7.09 & 6.45 & 6.13 & 5.94 & 0.33 \\
\hline & Allatoin (mmol/d) & 5.24 & 4.63 & 4.49 & 4.23 & 0.30 \\
\hline & $\begin{array}{c}\text { Xan+Hypoxan } \\
(\mathrm{mmol} / \mathrm{d})\end{array}$ & 0.67 & 3.76 & 0.85 & 0.57 & 0.84 \\
\hline & Uric acid (mmol/d) & 1.18 & 1.16 & 1.06 & 1.16 & 0.06 \\
\hline & Microbial N (g/d) & 5.08 & 4.64 & 4.49 & 4.09 & 0.27 \\
\hline \multirow[t]{5}{*}{5} & Total PDe (mmol/d) & 4.86 & 4.25 & 4.00 & 3.95 & 0.19 \\
\hline & Allatoin (mmol/d) & 3.82 & 3.51 & 3.46 & 3.41 & 0.15 \\
\hline & $\begin{array}{c}\text { Xan+Hypoxan } \\
(\mathrm{mmol} / \mathrm{d})\end{array}$ & 0.84 & 0.55 & 0.34 & 0.34 & 0.08 \\
\hline & Uric acid (mmol/d) & 0.20 & 0.20 & 0.20 & 0.20 & 0.00 \\
\hline & Microbial N (g/d) & 3.51 & 2.88 & 2.54 & 2.59 & 0.17 \\
\hline
\end{tabular}

PDe = Purine derivative excretion. $\mathrm{N}=$ Nitrogen. Xan+Hypoxan = Xanthene and hyposanthine. SEM = Standard error of mean.

Different superscripts within rows denote significant differences $(\mathrm{p}<0.05)$.

The shade dried Acacia and Albizia foliage contained consistently more tannin than the Sesbania foliage and most of that tannin appeared to be of the hydrolysable rather than condensed type. The hydrolysable tannin (HT) content of the Acacia and Albizia, in terms of the gallotannin assay, was 4.6 to 2.5 times more concentrated than that estimated for CT using the Butanol-HCl assay. The protein precipitation capacity of forage is particularly dependent on its content of HT (Makkar et al., 1991) and consistent with this the Acacia and Albizia foliage reacted strongly with the Protein precipitable phenolics assay. Values obtained by Filter paper and Radio-labeled methods are comparable for Acacia and Albizia, while the radial diffusion method was less sensitive for Albizia.

According to almost all of the tannin assays, shade drying reduced the concentration of tannins from 2 to $134 \%$ of the original concentrations, for Acacia and Albizia. A similarly dramatic decline in the concentration of extractable free and total CT has been shown in Calliandra (Perez-Maldonado and Norton, 1996; Wina et al., 1999) and Gliricidia (Ahn et al., 1989) foliage following drying. It is assumed that drying causes tannins to bind to cell wall in the plant DM rendering it unavailable for extraction. Whether these declines in tannin content translate into improved animal performance requires testing in vivo before any clear recommendations on the benefits of drying to feeding value can be made.

The in sacco degradability of the foliages appeared more related to assayable fiber content than to tannin content. Tannins can reduce the digestibility of DM in forages, although the effect is inconsistent (Barry et al.,
2001; Makkar, 2003). Yet in the current study, the foliage with the highest tannin content, Acacia, also had the highest extent and rate of digestion in the rumen. By contrast, the extent of digestibility of the Albizia in the rumen was less than half that for the Acacia. The Albizia did contain a moderate level of tannin but had nearly twice the level of NDF and more than 5 times the level of lignin than the Acacia. Fiber and particularly lignin content are key factors influencing the digestibility of DM and consequently the availability of energy in forage (Van Soest, 1994). However, any assessment of the extent to which fiber content impedes energy availability in tanniniferous forages is complicated by the ability of tannins to interfere with current fiber assays. Tannins tend to inflate the results of fiber assays and the extent of this interference is unpredictable and so cannot be corrected for (Van Soest, 1994). Hence, the question of whether the digestibility of tanniferous forages is more influenced by cell wall content than tannin content awaits the development of an improved assay for the determination of fiber in them.

The increase in gas production and rate of synthesis of microbial mass following the addition of PEG provides a measure of the effects of tannin on the rate of fermentation of forage that is independent of fiber content (Makkar et al., 1995; Makkar and Becker, 1996). The increase in gas production when PEG was added in the current study showed that the tannins were inhibiting fermentation in all 3 of the foliages tested, and especially so for the tannin-rich Acacia. However, consistent with a higher fiber level being a more important limiter of fermentation rate than tannin 
level, with or without PEG, the rate of fermentation and synthesis of microbial protein in the Albizia was less than a third and half respectively compared to the Acacia and the Sesbania. Compared to such a difference, the increase in gas production and microbial RNA synthesis in response to the addition of PEG was similar and relatively small (16$17 \%$ ) for the Albizia and Sesbania. The effects of tannin on fermentation rate may therefore be only of importance at higher concentrations (Osuga, et al., 2005) such as those seen in the Acacia.

The short term in vivo trial was designed to offer 3 levels of tannins and 15,10 or $5 \mathrm{~g}$ of $\mathrm{N}$ intake per day across 3 feeding periods. However, throughout the trial the sheep offered the tanniniferous foliage showed a preference for grass hay. This was likely a consequence of the sheep having had no experience with the foliages prior to the trial. Consequently, the desired intake of $\mathrm{N}$ per day in the foliage supplemented groups was not achieved during the first 2 levels of feeding. Although the high variance in feed intake meant a significant effect of treatment on feed intake was not found it appeared that the least preferred foliage was Acacia, followed by Albizia and Sesbania. The variation in feed intake may be related to differences in odor between the forages, as observed in other foliages (Abdulrazak et al., 1996; Stewart et al., 1998). High concentrations of tannins can depress intake. Forages containing 5.5\%-10.6\% CT could depress voluntary feed intake from $12 \%$ and $27 \%$ (Barry and Duncan, 1984; Waghorn et al., 1994), but levels of 3.4-4.4\% of CT appear unimportant (Wang et al., 1996). The foliages in the current trial had an even lower content of CT ( $<1 \%$ DM), although TP did reach $12 \%$ of DM in the shade dried Acacia indicative that tannins other than CT could still be part of the intake problem.

Of the 3 forages, the availability of nitrogen in terms of apparent digestibility and $\mathrm{N}$ balance also tended to be lowest in the tannin-rich Acacia, and highest in the Sesbania, which contained minimal tannin. However, this effect only reached significance at the highest level of tannin and $\mathrm{N}$ intake. Tannins consistently reduce the digestibility of protein in forages (McNeill et al., 1998, Barry et al., 2001) and these data fit that general hypothesis. Yet, surprisingly, the yield of microbial $\mathrm{N}$, as defined by the urinary excretion of purines technique, was higher in the Acacia compared to both the Albizia and Sesbania treatments. Remembering too that rate of synthesis of microbial RNA in vitro was also higher for Acacia than for the other 2 foliages, despite its higher tannin content, it seems the types of tannins or tannin-like substances in the Acacia may not bear deleterious to rumen microbes as expected. The relatively poorer utilization of $\mathrm{N}$ in the Acacia treatment could instead be a consequence of a post-ruminal inhibition of digestion and or metabolism. Before the effects of CT on protein digestibility, cellulolytic activity and post ruminal digestibility become apparent, concentrations need to be within the range of 2-10.6\% (Barry and Manley, 1984; Waghorn, 1990; Kumar, 1992; Pritchard et al., 1992; PerezMaldonado and Norton, 1996; Norton and Ahn, 1997; Norton, 1999). The concentrations of CT in the current study were below this range but the data suggests that the other types of tannins in the Acacia, with their high protein precipitating capacities, were sufficient to allow dietary protein to escape ruminal fermentation, as evident from the trend of high faecal $\mathrm{N}$ excretion, but impede post ruminal digestion, as evidenced by depressed excretions of urinary $\mathrm{N}$.

Sesbania ranked as the most nutritionally promising of the 3 foliages tested. $\mathrm{N}$ balance in the sheep fed the Sesbania was similar to that in the sheep fed the concentrate, and was superior to that achieved with the other foliages. In vivo and in sacco digestibility of DM and OM for Sesbania was similar to the Acacia and better than Albizia, as was gas production in vitro. It was only in terms of the ability to support the synthesis of microbial protein that Sesbania appeared less effective than Acacia, and since it appeared to provide sufficient $\mathrm{N}$, the limiting factor that sheep supplemented with Sesbania may respond to most is more rumen fermentable energy.

\section{CONCLUSION}

Sesbania contained minimal amounts of tannins, compared to Albizia, and Acacia. Acacia was particularly rich in tannins, of the non-condensed type. Drying reduced the content of tannins in Acacia and Albizia according to almost all of the tannin assays used and the addition of PEG improved the ability of microbes to ferment the foliages. Of the 3 foliages, Sesbania showed the most potential as a protein supplement, whilst Albizia was most limited by it lower availability of digestible energy and protein.

\section{ACKNOWLEDGEMENTS}

The authors gratefully acknowledge the financial grant from the International Atomic Energy Agency, Vienna through Coordinated Research Project no. 10266.

\section{REFERENCES}

AOAC. 1990. Official Methods of Analysis. 15th ed., Association of Official Analytical Chemists, Washington, DC.

Abdulrazak, S. A., R. W. Muinga, W. Thorpe and E. R. Ørskov. 1997. Supplementation with Gliricidia Sepium and Leucaena leucocephala on voluntary feed intake, digestibility, rumen fermentation and live-weight of crossbred steers offered Zea mays stover. Livestock Prod. Sci. 49:53-62. 
Ahn, J. H., B. M. Robertson, R. Elliott, R. C. Gutteridge and C. W. Ford. 1989. Quality assessment of tropical browse legumes tannin content and protein degradation. Anim. Feed Sci. Technol. 27:147-156.

Alam, M. R. 1998. Potential use legume tree leaves as forage in Bangladesh. In: Nitrogen fixing trees for fodder production. (Ed. J. N. Daniel and J. M. Roshetko). Winrock International, USA, pp. 205-211.

Barry, T. N. and S. J. Duncan. 1984. The role of condensed tannins in the nutritional value of $L$. pedunculatus for sheep. 1 . Voluntary intake, Br. J. Nutr. 51:485-491.

Barry, T. N. and T. R. Manley. 1984. The role of condensed tannins in the nutritional value of L. pedunculatus for sheep. 2. Quantitative digestion of carbohydrates and proteins. Br. J. Nutr. 51:493-504.

Barry, T. N., M. D. McNeill and W. C. McNabb. 2001. Plant secondary compounds; their impact on nutritive value and upon animal production. In: Proceedings of the XIX International Grassland Congress. Brazilian Society of Animal Husbandry, Piracicaba., pp. 445-452.

Bhargava, P. K. and E. R. Ørskov. 1987. Manual for the use of nylon bag technique in the evaluation of foodstuffs. Rowett Research Institute, UK.

Chen, X. B., J. D. F. Mathieson, Dev. Hovell and P. J. Reeds. 1990. Measurement of purine derivatives in urine of ruminants using automated methods. J. Sci. Food Agric. 53:23-33.

Dawra, R. K., H. P. S. Makkar and B. Singh. 1988. Protein binding capacity of microquantities of tannins. Anal. Biochem. 170:5053.

Evaitayani, L., A. Warly, A. Fariani, T. Ichinohe and T. Fujihara 2004. Study on nutritive value of tropical forages in North Sumatra, Indonesia. Asian-Aust. J. Anim. Sci. 17:1518-1523.

Faichney, G. J. and G. A. White. 1983. Methods for the analysis of feeds eaten by ruminants. CSIRO, Australia.

Hagerman, A. E. 1987. Radial diffusion method for determining tannins in plant extracts. J. Chem. Ecol. 13:437-449.

Hagerman, A. E., M. E. Rice and N. T. Ritchard. 1998. Mechanisms of protein precipitation for two tannins, pentagalloyl glucose and epicatechin(16) (4>8) catechin (procyanidin). J. Agric. Food Chem. 46:2590-2595.

Inoue, H. and A. E. Hagerman. 1988. Determination of gallotannins with rhodanine. Anal. Biochem. 169:363-369.

IAEA. 1997. Estimation of rumen microbial protein production from purine derivatives in urine. A Laboratory Manual. International Atomic Energy Agency Technical Document, IAEA-TECDOC-945, pp. 15-37.

Kumar, R. 1992. Anti-nutritional factors, the potential risks of toxicity and methods to alleviate them. In: Legume trees and other fodder trees as protein sources for livestock (Ed. A. Speedy and P. L. Pugliese) FAO Animal Production and Health Paper 102. Food and Agriculture Organisation of the United Nations, Rome.

Lawry, J. B. 1990. Toxic factors and problems: Methods of alleviating them in animals. In: Shrubs and Tree fodders for Farm (Ed. C. Devendra). IDRC, Canada, pp. 76-88.

Makkar, H. P. S. 2003. Effects and fate of tannins in ruminant animals, adaptation to tannins, and strategies to overcome detrimental effects of feeding tannin-rich feeds. Small Rum. Res. 49:241-256.
Makkar, H. P. S., R. K. Dawra and B. Singh. 1988. Determination of both tannin and protein in a tannin-protein complex. J. Agric. Food Chem. 36:523-525.

Makkar, H. P. S., K. D. Rajinder and B. Singh. 1991. Tannin levels in leaves of some Oak species at different stages of maturity. J. Sci. Food Agric. 54:513-519.

Makkar, H. P. S., M. Bluemmel, N. K. Borowy and K. Becker. 1993. Gravimetric determination of tannins and their correlations with chemical and protein precipitation methods. J. Sci. Food Agric. 61:161-165.

Makkar, H. P. S., M. Blummel and K. Becker. 1995. Formation of complexes between polyvinylpyrrolidone and polyethylene glycol with tannins and their implications in gas production and true digestibility in in vitro techniques. Br. J. Nutr. 73:897913.

Makkar, H. P. S. and K. Becker. 1996. A bioassay for phenols (Tannins). Polyphenols Communications, Bordeaux (France), 96:15-18.

Makkar, H. P. S. and K. Becker. 1999. Purine quantification in digesta from ruminants by spectrophotometric and HPLC methods. Br. J. Nutr. 81:107-113.

Mangan, J. L. 1988. Nutritional effects of tannins in animal feeds. Nutr. Res. Rev. 1:209-231.

Manke, K. H., L. Raab, A. Salewski, H. Steingass, D. Fritz and W. Schneider. 1979. The estimation of the digestibility and metabolizable energy content of ruminant feedingstuffs from the gas production when they are incubated with rumen liquor in vitro. J. Agric. Sci. (Camb) 93:217-222.

McNeill, D. M. N. Osborne, M. K. Komolong and D. Nankervis. 1998. Condensed tannins in the Genus Leucaena and their nutritional significance for ruminants. In: LeucaenaAdaptation, Quality and Farming Systems (Ed. H. M. Shelton, R. C. Gutteridge, B. F. Multen and R. A. Bray). ACIAR Proceedings No. 86, Canberra, Australia, pp. 205-214.

Norton, B. W. 1999. The significance of tannins in tropical animal production. In: Tannins in livestock and human nutrition (Ed. J. D. Brooker). ACIAR Proceedings no. 92, Canberra, Australia, pp. 14-23.

Norton, B. W. and H. H. Ahn. 1997. A comparison of fresh and dried Calliandra calothyrsus supplements for sheep given a basal diet of barley straw. J. Agric. Sci. 129:485-494.

Osuga, I. M., S. A. Abdulrazzak, T. Ichinohe and T. Fujihara. 2005. Chemical composition, degradation characteristics and efeect of tannins on digestibility of some browse species from Kenya harvested during the wet season. Asian-Aust. J. Anim. Sci. 18:54-60.

Perez-Maldonado, R. A. and B. W. Norton. 1996. The effects of condensed tannins from Desmodium intortum and Calliandra calothyrsus on protein and carbohydrate digestion in sheep and goats. Br. J. Nutr. 76:515-533.

Pritchard, D. A., P. R. Martin and P. K. O’Rourke. 1992. The role of condensed tannins in the nutritional value of mulga (Acacia aneura) for sheep. Aust. J. Agric. Res. 43:1739-1746.

Porter, L. J., L. N. Hrstich and B. G. Chen. 1986. The conversion of procyanidins and prodelphinidins to cyaniding and delphinidin. Phytochemistry 25:223-230.

Reed, J. D., H. Soller and A. Woodward. 1990. Fodder tree and straw diets for sheep: intake, growth, digestibility and the effect of phenolics on nitrogen utilization. Anim. Feed Sci. 
Technol. 30:39-50.

Statistical Analysis Systems Institute, 1988. Procedures Guide for Personal Computers. Version 6.03, SAS Institute Inc., Cary, NC.

Stewart, J. L., A. L. Dansdon, M. Kass, S. Ortiz Lopez, A. Larbi, S. Premaratne, B. Tangendjaja, E. Wina and J. E. Vargas. 1998. Acceptability, intake, digestibility and live weight gain in small ruminants. Anim. Feed Sci. Technol. 75:111-124.

Van Soest, P. J. 1994. Nutritional Ecology of the Ruminant, Second Edition. Comstock Pub., Ithaca.

Waghorn, G. C. 1990. Effects of condensed tannin on protein digestion and nutritive value of fresh herbage. Proceedings of the Australian Society of Animal Production, 18:412-415.
Waghorn, G. C., I. D. Shelton, W. C. McNabb and S. H. McCutcheon. 1994. Effects of condensed tannins in $L$. pedunculatus on its nutritive value for sheep. 2. Nitrogenous aspects. J. Agric. Sci. 123:109-119.

Wang, Y., G. B. Douglas, G. C. Waghorn, T. N. Barry, A. G. Foote and R. W. Purchas. 1996. Effect of condensed tannins upon the performance of lambs grazing $L$. corniculatus and lucerne. J. Agric. Sci. 126:87-98.

Wina, E., B. Tangedjaja and B. Palmer. 1999. The effect of drying conditions on condensed tannin estimates in calliandra calothyrsus. In: Tannins in livestock and human nutrition. (Ed. J. D. Brooker). ACIAR Proceedings no. 92, Canberra, Australia, pp. 106-110. 